\title{
Akuntabilitas Keuangan Desa dan Kesejahteraan Aparatur Desa dalam Pengelolaan Keuangan Desa
}

\author{
Yusuf Eko Nahuddin
}

Yusuf Eko Nahuddin; Fakultas Hukum Universitas Merdeka Malang; Jl. Terusan Dieng No.62-64; Malang; 65115; Indonesia.

\begin{tabular}{l} 
A R T I C L E IN F O \\
\hline Article history: \\
Received 2018-04-20 \\
Received in revised form \\
2018-05-20 \\
Accepted 2018-06-01
\end{tabular}

Kata kunci:

Akuntabilitas; Aparatur Desa;

Keuangan Desa;

\section{Keywords:}

Accountability; Village Apparatus; Village Finance;

\begin{abstract}
Abstrak
Semangat Desa membangun merupakan kata kunci lahirnya UndangUndang No. 6 tahun 2014 tentang Desa, yang harus diwujudkan dengan upaya pengelolaan keuangan desa yang profesional guna terciptanya kesejahteraan masyarakat dan aparatur desa sebagai konsekuensi yuridis atas berlakunya Undang-Undang No. 6 tahun 2014 tentang Desa yang berkaitan dengan kewenanganotonom untuk mengelola keuangan desa secara akuntabel demi tercapainya kesejateraan desa yangmenjadi keinginan bersama dan cita-cita luhur bangsa ini dan juga tidak kalah pentingnya adalah peningkatan kesejahteraan aparatur desa untuk menunjang cita-cita tersebut sehingga tidak berpotensi adanya penyalahgunaan wewenang. Berbicara mengenai desa, tidak terlepas dari kedudukan dan kewenangan pemerintah desa, sebagai unit pemerintah terendah di Indonesia yang masih banyak pula menimbulkan pro dan kontra di kalangan pemerintah desa itu sendri, salah satu penyebabnya adalah Otonomi Daerah yang kurang memerikan ketegasan tentang tugas dan kewenangan kepala desa, untuk mengelola keuangan nya sendiri, keuangan yang di peroleh Desa dari APBN (Anggaran Pendapatan dan Belanja Negara) yang dirupaka dalam bentuk ADD (Alokasi Dana Desa).
\end{abstract}

\begin{abstract}
The spirit of the Village building is the key word for the birth of Law No. 6 of 2014 concerning Villages, which must be realized with the efforts of professional village financial management to create community welfare and village apparatus as a juridical consequence of the enactment of Law No. 6 of 2014 concerning Villages relating to autonomous authority to manage village finance accountably for the achievement of village welfare which is a shared desire and noble ideals of the nation and also equally important is to improve the welfare of village apparatus to support these ideals so that they have no potential abuse of authority. Speaking
\end{abstract}

Corresponding Author:

Yusuf Eko Nahuddin

Email address: yusuf.nahuddin@unmer.ac.id DOI: https://doi.org/10.26905/idjch.v9i1.2111 


\section{Jurnal Cakrawala Hukum I Volume 9 No. 1 Juni 2018}

ISSN PRINT 2356-4962 ISSN ONINE 2598-6538

about the village, it is inseparable from the position and authority of the village government, as the lowest government unit in Indonesia which still raises the pros and cons of the village government itself, one of the reasons is Regional Autonomy which lacks assertiveness about the task and authority of the village head, to manage its own finances, the finance obtained by the Village from the APBN (State Revenue and Expenditure Budget) is in the form of ADD (Village Fund Allocation).

\section{Latar Belakang}

Menurut Lampiran Peraturan Menteri Dalam Negeri Nomor 18 Tahun 2013, jumlah seluruh Desa yang tercatat di Indonesia sejumlah 72.944. Definisi Desa itu sendiri menurut Pasal 1 angka 1 UndangUndang Nomor 6 Tahun 2014 Tentang Desa (selanjutnya disebut UU Desa) menyebutkan Desa adalah desa dan desa adat atau yang disebut dengan nama lain, selanjutnya disebut Desa, adalah kesatuan masyarakat hukum yang memiliki batas wilayah yang berwenang untuk mengatur dan mengurus urusan pemerintahan, kepentingan masyarakat setempat berdasarkan prakarsa masyarakat, hak asal usul, dan/atau hak tradisional yang diakui dan dihormati dalam sistem pemerintahan Negara Kesatuan Republik Indonesia, dan dengan kata lain desa adalah kesatuan masyarakat hukum yang memiliki kewenangan mengatur dan mengurus kepentingan rumah tangganya sendiri yang disesuaikan dengan kebutuhan dari desa setempat, artinya desa itu memiliki hak otonomi.

Berkaitan dengan keuangan desa, menurut Peraturan Pemerintah Nomor 43 Tahun 2014 tentang Peraturan Pelaksana Undang-undang Nomor 6 Tahun 2014 Tentang Desa menjelas pasal 1 angka 8 menyebutkan Dana desa adalah dana yang bersumber dari anggaran pendapatan dan belanja negara yang diperuntukkan bagi Desa yang ditransfer melalui anggaran pendapatan dan belanja daerah kabupaten/kota dan digunakan untuk membiayai penyelenggaraan pemerintahan, pelak- sanaan pembangunan, pembinaan kemasyarakatan, dan pemberdayaan masyarakat.

Menurut Pasal 71 Undang-Undang Nomor 6 Tahun 2014 Tentang Desa menyebutkan bahwa keuangan desa adalah semua hak dan kewajiban Desa yang dapat dinilai dengan uang serta segala sesuatu berupa uang dan barang yang berhubungan dengan pelaksanaan hak dan kewajiban Desa dan pelaksanaan hak dan kewajiban tersebut menimbulkan pendapatan, belanja, pembiayaan, dan pengelolaan Keuangan Desa. Lebih lanjut dalam Pasal 72 Undang-undang Nomor 6 Tahun 2014 tentang Desa bahwa Pendapatan Desa sebagaimana dimaksud bersumber dari; a) pendapatan asli Desa terdiri atas; hasil usaha, hasil aset, swadaya dan partisipasi, gotong royong, dan lain-lain pendapatan asli Desa; b) alokasi Anggaran Pendapatan dan Belanja Negara (Dana Desa 10\% dari dana transfer ke daerah); c) bagian hasil pajak daerah dan retribusi daerah Kabupaten/Kota (paling sedikit 10\% dari realisasipajak/retribusi daerah); d) Alokasi Dana Desa $(A D D)$ yang merupakan bagian dari dana perimbangan yang diterima Kabupaten/Kota (paling sedikit $10 \%$ dari realisasi dana perimbangan yang diterima); e) bantuan keuangan dari Anggaran Pendapatan dan Belanja Daerah Provinsi dan Anggaran Pendapatan dan Belanja Daerah Kabupaten/ Kota; f) hibah dan sumbangan yang tidak mengikat dari pihak ketiga; g) dan lain-lain pendapatan Desa yang sah.

Undang-Undang Nomor 27 tahun 2014 tentang APBN Tahun Anggaran 2015 Dana Desa 
dianggarkan dalam Pasal 9 ayat (3) direncanakan sebesar Rp 9.066.200.000.000,00 (sembilan triliun enam puluh enam miliar dua ratus juta rupiah). Anggaran Dana Desa ini masih dalam kisaran 1,4\% dari total anggaran transfer ke daerah dalam APBN 2015. Budiman Sudjatmiko menyatakan alokasi anggaran desa senilai Rp9,1 triliun atau 1,4 persen dari total dana transfer daerah dalam rancangan Anggaran Pendapatan dan Belanja Negara 2015, belum mencerminkan semangat Undang Undang Desa Nomor 6 Tahun 2014. Meskipun dengan alasan akan dievaluasi lagi dan ditingkatkan secara bertahap, namun menurut hemat saya angka Rp9,1 Triliun anggaran desa masih jauh dari harapan. Sebab, Undang-Undang Nomor 6 Tahun 2014 Tentang Desa mengamanatkan kepada pemerintah mengalokasikan anggaran Dana Desa sebesar 10 persen di luar dana transfer daerah. Ini berarti dengan menggunakan angka pada RAPBN 2015 sebesar Rp640 triliun, semestinya Dana Desa mencapai sebesar Rp64 triliun. Dengan alokasi dana sebesar Rp 9,1 Triliun, atau hanya 1,4 persen dari Dana Transfer Daerah, itu berarti pemerintahan sekarang ini belum mampu menjawab semangat Undang-Undang Nomor 6 Tahun 2014 Tentang Desa (Kompas.com, 2014).

Dalam penggunaan keuangan desa sebelum diterbitkannya Undang-Undang Nomor 6 Tahun 2014 Tentang Desa, yang menjadi dasar hukum turunnya Dana Desa, telah banyak Kepala Desa, Anggota DPRD yang tersangkut kasus korupsi Alokasi Dana Desa. Dengan adanya Dana Desa yang bersumber dari APBN memicu kekhawatiran dari beberapa pihak antara lain Wakil Ketua Komisi Pemberantasan Korupsi (KPK) Adnan Pandu Praja yang menyatakan pihaknya akan menyurati seluruh aparat desa di Indonesia untuk mengingatkan agar alokasi Dana Desa dimanfaatkan dengan benar dan tidak melanggar hukum, apalagi korupsi (Hukumonline.com, 2014).

Kekhawatiran beberapa pihak mengenai penggunaan keuangan desa cukup beralasan meng- ingat dari 72.944 desa yang ada di Indonesia, belum ada basis data yang dimiliki Pemerintah Pusat terkait kualitas sumber daya manusia perangkat desa, terlebih dibeberapa wilayah di Indonesia pemilihan perangkat desa diduga masih disinyalir menggunakan money politic dalam proses pemilihan langsungnya.

Sukasmanto Peneliti Ahli dari Institute for Research and Empowerment (IRE) dalam forum Anti Korupsi Indonesia memaparkan potensi penyalahgunaan Dana Desa dipengaruhi oleh 4 hal yakni bagaimana peraturan turunan dari UndangUndang Nomor 6 Tahun 2014 Tentang Desa termasuk peraturan Dana Desa, tinggi/rendahnya tingkat diskresi pengelolaan keuangan desa, tinggi/rendahnya kualitas sumber daya manusia dan pembinaan/pengawasan penggunaan Dana Desa (Sukasmanto-IRE, 2014).

Salah satu penyebab praktek korupsi di Indonesia adalah rendahnya kesejahteraan para aparaturnya dalam pemerintahan desa, seorang Kepala Desa dan Perangkat Desa telah diatur hak-hak keuangannya sejak diterbitkannya Peraturan Pemerintah Nomor 72 Tahun 2005 tentang Desa dan Peraturan Pemerintah Nomor 43 Tahun 2014 tentang Peraturan Pelaksana Undang-undang Nomor 6 Tahun 2014 Tentang Desa (selanjutnya disebut PP Desa) sebagai penggantinya. Perbedaan kedua peraturan pemerintah dimaksud perihal terletak pada besaran penghasilan tetap, menurut Pasal 27 ayat (3) Peraturan Pemerintah Nomor 72 Tahun 2005 penghasilan tetap Kepala Desa dan Perangkat Desa perbulan paling sedikit sama dengan Upah Minimum Regional Kabupaten/Kota sedangkan menurut Pasal 81 PP Desa besarannya diukur berdasarkan presentase Alokasi Dana Desa yang ditetapkan oleh Kepala Daerah.

Perbaikan kesejahteraan para Kepala Desa dan Perangkat Desa sudah pernah digaungkan oleh Asosiasi Kepala Desa ( $A K D$ ) Jawa Timur dalam sebuah aksi damai di gedung DPR tahun 2010 silam (Vivanews.co.id, 2010). Merujuk kebijakan baru 


\section{Jurnal Cakrawala Hukum I Volume 9 No. 1 Juni 2018}

ISSN PRINT 2356-4962 ISSN ONINE 2598-6538

pemerintah yang mengucurkan Dana Desa sehingga pendapatan desa bertambah dari APBN dan praktek pengelolaan keuangan desa disampaikan beberapa permasalahan sebagai mana yang disebutkan diatas. Dengan dengan demikian timbulah suatu permasalahan yag cukup urgen untuk diberikan suatu solusi yakni bagaimana mekanisme pengelolaan keuangan desa berdasarkan prinsip akuntabiitas.

Serta yang tidak kalah pentingnya sebagai satu kesatuan sistem permasalahan juga berkaitan dengan bagaimana pengalokasian peningkatan kesejahteraan aparatur Desa menurut peraturan perundang-undangan yang berlaku. Sehingga tidak rawan terjadinya penyimpangan serta penyalahgunaan Dana Desa yang sesungguhnya menurut semangat lahirnya Undang-undang Nomor 6 tahun 2014 tentang Desa adalah untuk mensejahterakan masayarakat desa yang merupakan elemen ter inti dari kedaulatan negera dan bangsa indonesia ini karena merupakan basis warga negara khususnya indonesia sehingga tidak termarjinalkan dengan masyarakat perkotaan dengan harapan kesejahteraan semakin merata sebagaimana tujuan negara indonesia ini yakni mensejahterakan kehidupan bangsa tanpa terkecuali.

\section{Metode}

Jenis penelitian dalam menggunakan penelitian normatif-empiris. Penelitian normatif yaitu penelitian yang dilakukan untuk menelaah kaidah hukum normatif yang dilihat dari segi penerapannya. Penelitian normatif ini dilakukan untuk mencermati bagaimana ketentuan-ketentuan dalam Undang-Undang Desa. Penelitian ini menggunakan pendekatan yuridis normatif dengan studi kasus hukum (judicial case study). Penelitian ini menggunakan pendekatan yuridis karena berpijak pada ketentuan-ketentuan hukum di bidang desa sebagai dasar normatif.

\section{Pembahasan}

\section{Penyelenggaraan Pemerintah Desa}

Pemerintah desa sebagai unit lembaga yang berdekatan dengan masyarakat, posisi dan kedudukan hukumnya hingga saat ini selalu jadi perdebatan terutama ditingkat elit politik. Melalui penerapan Undang-Undang Nomor 32 Tahun 2004 Tentang Pemerintah Daerah selain menimbulkan implikasi pada perubahan dalam relasi kekuasaan antar kekuatan politik di level desa.

Perubahan ke arah interaksi yang demokratik itu terlihat dari beberapa fenomena, diantaranya: a. dominasi peran birokrasi mengalami pergeseran digantikan dengan menguatnya peran institusi adat dalam proses penyelenggaraan pemerintah sehari-hari; b. semangat mengadopsi demokrasi-liberatif cukup besar dalam Undang-Undang yang baru, misalnya dengan hadirnya BPD (Badan Permusyawaratan Desa). Dimana badan legislatif baru ini berperan sebagai pengayom adat-istiadat yang memiliki tugas dan wewenang untuk, membuat Peraturan Desa bersama dengan Kepala Desa, menampung dan menyalurkan aspirasi masyarakat, serta melakukan pengawasan terhadap penyelenggaraan pemerintah Desa; c. semangat pertisipasi masyarakat sangat ditonjolkan. Artinya proses politik, pemerintah dan pembangunan di desa tidak lagi bermuara dari kebijakan pemerintah pusat secara terpusat, melainkan berasal dari partisipasi masyarakat (Moch. Solekhan, 2012).

Di dalam Undang-Undang Dasar 1945 pasal 18 yang isinya berkaitan tentang pemerintah daerah menyebutkan bahwa Negara Kesatuan Republik Indonesia dibagi atas daerah-daerah provinsi, dan dari daerah provinsi itu di bagi atas kabupaten dan kota, yang tiap-tiap provinsi, kabupaten dan kota itu mempunyai pemerintahan daerah dan dari setiap daerah kabupaten terdapat komunitas yang bernama desa, yang diatur dengan Undang-undang. Dari pernyataan tersebut di atas dapat ditarik kesimpulan bahwa desa merupakan bagian yang 


\section{Akuntabilitas Keuangan Desa dan Kesejahteraan Aparatur Desa dalam Pengelolaan Keuangan Desa}

Yusuf Eko Nahuddin

tidak terlepaskan dari pemerintah daerah, dengan kata lain urusan desa menjadi tanggung jawab pemerintah daerah.

Definisi desa secara keseluruhan yang berkaitan dengan pembentukan desa dengan memperhatikan syarat-syarat luas wilayah, jumlah penduduk dan syarat-syarat lain yang akan ditentukan lain oleh Peraturan Pemerintah Nomor 43 Tahun 2014 tentang Peraturan Pelaksana UndangUndang Nomor 6 Tahun 2014 Tentang Desa.

Asas penyelenggaraan pemerintahan desa dalam Pasal 24 Undang-Undang No. 6 tahun 2014 Tentang Desa adalah kepastian hukum, tertib penyelenggaraan pemerintahan, tertib kepentingan umum, keterbukaan, proporsionalitas, profesionalitas, akuntabilitas, efektivitas/efisiensi, kearifan lokal, keberagaman dan partisipatif.

Pembentukan nama, batas, kewenangan, hak dan kewajiban desa ditetapkan dan diatur dengan Paraturan Daerah, yang artinya desa memliki daerah otonomi sendiri yang langsung dibawah Camat, dengan kata lain, otonomi itu sendiri berdasarkan atas asal-usul adat-istiadat setempat yang mengandung pengertian otonomi yang telah dimiliki sejak dahulu kala dan telah menjadi adat-istiadat yang melekat dalam masyarakat desa yang bersangkutan. Selain desa ada pula pemerintahan yang terendah yang langsung dibawah Camat yang disebut sebagai Kelurahan yang terdapat di ibu kota provinsi, ibu kota kabupaten, kotamadya, dan kotakota lain.

Dengan terbentuknya suatu daerah yang disebut, baik desa ataupun kelurahan, dengan tatar- an pemerintahan terendah yang langsung di bawah Camat, tugas Pemerintah Desa dan Pemerintah Kelurahan dibantu oleh Perangkat Desa dan Perangkat Kelurahan. Kepala Desa dan Kepala Kelurahan berperan aktif dalam kesejahteraan aparatur dan perang-perangkat desa dalam penge- lolaan salah satunya adalah keuangan desa, dan juga kepala desa dan kepala kelurahan sebagai orang pertama mengemban tugas dan kewajiban yang berat, karena ia adalah penyelanggara dan penanggung jawab utama dalam bidang pemerintahan, pembangunan, kemasyarakatan, dan urusan pemerintah umum termasuk pembinaan ketenteraman dan ketertiban (Kansil, 1984).

Pemerintahan yang di pimpin oleh seorang Kepala Desa menjalankan hak, wewenang, dan kewajiban pimpinan pemerintah desa yaitu menyelenggarakan rumah tangganya sendiri dan merupakan penyelenggara dan penanggung jawab utama dalam bidang pemeritahan, pembangunan dan kemasyarakatan dalam rangka penyelanggara urusan pemeritah desa, urusan pemerintah desa umumnya termasuk pembinaan ketenteraman dan ketertiban sesuai dengan peraturan perundangundang yang berlaku dan menumbuhkan serta mengembangkan jiwa gotong royong masyarakat sebagai sendi utama pelaksanaan pemerintah desa.

Berbicara mengenai desa, tidak terlepas dari kedudukan dan kewenangan pemerintah desa, sebagai unit pemerintah terendah di Indonesia yang masih banyak pula menimbulkan pro dan kontra di kalangan pemerintah desa itu sendri, salah satu penyebabnya adalah Otonomi Daerah yang kurang memerikan ketegasan tentang tugas dan kewenangan kepala desa, untuk mengelola keuangan nya sendiri, keuangan yang di peroleh Desa dari APBN (Anggaran Pendapatan dan Belanja Negara) yang dirupaka dalam bentuk ADD (Alokasi Dana Desa).

\section{Mekanisme Pengelolaan Keuangan Desa Berdasarkan Prinsip Akuntabelitas}

Berdasarkan asas pemerintahan yang baik otonomi daerah yang ada di dalam Negara Kesatuan Republik Indonesia ini sudah berjalan lebih dari satu dasa warsa, tetapi pemerintahan di daerah sampai saat ini masih menghadapi tantangan yang cukup besar dalam melakukan reformasi birokrasi. 


\section{Jurnal Cakrawala Hukum I Volume 9 No. 1 Juni 2018}

ISSN PRINT 2356-4962 ISSN ONINE 2598-6538

Berkenaan dengan upaya pemerintah untuk melakukan proses reformasi birokrasi tersebut terutama dalam konteks mendorong partisipasi public, yang cukup memberikan kontribusi terhadap penyelenggaraan pemerintahan yang baik. masyarakat yang menjadi obyek untuk mejadikan salah satu pilar "good governance" yang artinya pemerintahan yang baik tidak lagi di posisikan sebagai obyek pembangunan, tetapi telah diposisikan menjadi subyek pembangunan. Dengan kata lain, masyarakat memilik peran dan tanggung jawab yang tinggi dalam mendorong terwujudnya pemerintahan yang baik.

Dalam pembahasan ini penulis akan mendeskripsikan tentang gambaran kebijakan pemerintah yang khususnya, pemerintah kabupaten mengenai ADD (Alokasi Dana Desa) dalam hubungannya dengan partisipasi masyarakat dalam penyelenggaraan pemerintah desa dan kesejahteraan aparatur desa dalam pengembangan dan pengelolaan ke-

uangan desa. Kebijakan pengelolaan keuangan desa, yaitu Alokasi Dana Desa yang merupakan suatu ilustrasi untuk menggambarkan sejauh mana

komitmen pemerintah melibatkan masyarakat dalam penyelenggaraan pemerintah desa, khususnya dalam pengelolaan Alokasi Dana Desa (ADD).

Berkaitan dengan Alokasi Dana Desa (ADD), sebenarnya adalah merupakan program lanjutan dari dana bantuan desa sejak tahun 1969 yang disediakan oleh pemerintah pusat dalam bentuk Inpres Pembangunan Desa. Dalam perkembangannya, ke-

tika mulai di berlakukan otonomi daerah, ADD kemudian dialokasikan melalui APBD (Anggaran Pedapatan Belanja Daerah). Sejalan dengan pelaksanaan otonomi daerah tersebut, lebih lanjut pemerintah Kabupaten memberikan kepercayaan kepada pemerinah desa sebagai desa otonom untuk mengelolan anggaran sautu kegiatan sesuai dengan tugas pokok dan fungsinya, dengan harapan agar terciptanya kemandirian masyarakat dengan tetap melestarikan nilai-nilai gotong-royong yang ada di masyarakat.
Pemberian kepercayaan terhadap pemerintah desa itu sebagai desa otonom untuk mengelola anggaran suatu kegiatan tersebut tercermin melalui kebijakan pemerintah daerah. Kebijakan pemrintah daerah tersebut berupa peraturan daerah, bisa juga berupa Peraturan Bupati atau Keputusan Bupati, maupun kebijakan-kebijakan yang dikeluarkan oleh dinas/instansi terkait sebagai wujud dukungan untuk terimplementasikanya pengelolaan suatu kegiatan secara otonom.

Dengan demikian pemberian ADD (Alokasi Dana Desa) merupakan wujud dari pemenuhan hak desa untuk menyelenggarakan otonominya agar tumbuh dan berkembang mengikuti pertumbuhan dari desa itu sendiri berdasarkan keanekaragaman, partisipasi, otonomi asli, demokratisasi dan pemberdayaan masyarakat sesuai dengan arah dan kebijakan pembangunan desa itu sendiri.

Menurut Pasal 71 Undang-undang No. 6 tahun 2014 Tentang Desa menyebutkan bahwa keuangan desa adalah semua hak dan kewajiban desa yang dapat dinilai dengan uang serta segala sesuatu berupa uang dan barang yang berhubungan dengan pelaksanaan hak dan kewajiban desa dan pelaksanaan hak dan kewajiban tersebut menimbulkan pendapatan, belanja, pembiayaan, dan pengelolaan Keuangan Desa. Sementara Pasal 93 Peraturan Pemerintah Nomor 43 Tahun 2014 Tentang Peraturan Pelaksana Undang-undang Nomor 6 Tahun 2014 Tentang Desa atau yang disebut PP Desa, Pengelolaan keuangan Desa meliputi: perencanaan, pelaksanaan, penatausahaan, pelaporan dan pertanggungjawaban.

Implementasi dari keuangan desa tercermin dari APB Desa yang diterbitkan berdasarkan Peraturan Desa. Menurut PP Desa, dasar penyusunan APB Desa adalah Rencana Kerja Pemerintah (RKP) Desa yang disusun berdasarkan penjabaran Rencana Pembangunan Jangka Menengah (RPJM) desa untuk jangka waktu 1 tahun. Sementara RPJM Desa disusun dalam jangka waktu 6 tahun melalui musyawarah. Rancangan APB Desa diajukan oleh 
Kepala Desa dan dimusyawarahkan dengan Badan Permusyawarahan Desa (BPD) sebagaimana diatur dalam Pasal 73 Undang-Undang Nomor 6 Tahun 2014 Tentang Desa.

Bupati/Walikota memiliki kewenangan untuk melakukan evaluasi terhadap RAPB Desa yang diajukan Kepala Desa sebelum ditetapkan menjadi Peraturan Desa sebagaimana dimaksud Pasal 69 ayat (4) Undang-Undang Nomor 6 Tahun 2014 Tentang Desa. Persetujuan Bupati/Walikota terhadap RAPB Desa dalam rangka menilai ketepatan informasi kepada Gubernur/Bupati/Walikota terkait sumber pendapatan desa yang bersumber dari APBN/APBD sebagaimana Pasal 102 PP Tentang Desa.

Pendapatan desa Menurut Pasal 72 UndangUndang Nomor 6 Tahun 2014 Tentang Desa, sumber keuangan desa/pendapatan desa dapat di klasifikasikan menjadi 2 golongan yakni pendapatan yang bersumber dari APBN/APBD dan yang bersumber dari luar APBN/APBD. Pendapatan Desa yang bersumber dari APBN/APBD adalah Dana Desa, Bagi Hasil Pajak/Retribusi Daerah, Alokasi Dana Desa dan Bantuan Keuangan Kabupaten/ Kota/Provinsi.

Pendapatan Desa yang bersumber dari luar APBN/APBD adalah Pendapatan Asli Desa, Hibah Pihak Ketiga yang tidak mengikat dan Lain-Lain Pendapatan Desa yang Sah. Menurut Pasal 91 PP Desa, seluruh pendapatan Desa diterima dan disalurkan melalui rekening kas Desa dan penggunaannya ditetapkan dalam APB Desa.

Pencairan dana dalam rekening kas Desa ditandatangani oleh kepala Desa dan Bendahara Desa. Pemerintah mengalokasikan Dana Desa dalam anggaran pendapatan dan belanja negara setiap tahun anggaran yang diperuntukkan bagi Desa yang ditransfer melalui anggaran pendapatan dan belanja daerah kabupaten/kota.

Upaya peningkatan kinerja dan kapasitas penyelenggara Pemerintahan Desa dalam memberikan pelayanan dan pemberdayaan masyarakat tersebut, setiap desa mendapatkan ADD (Alokasi Dana Desa) yang bersumber dari bagian dana perimbangan keuangan pusat dan daerah. Menurut penjelasan pasal 4 ayat (1) Perda Nomor 18 Tahun 2006 tentang Alokasi Dana Desa, menyatakan bahwa "Bagian dari penerimaan dana perimbangan keuangan pusat dan daerah yang diterima pemerintah Kabupaten dialokasikan kepada Desa sebesar 10\% dari penerimaan dana perimbangan yang ditetapkan dalam $A P B D^{\prime \prime}$.

Penjelaskan pasal 2 ayat 1 dan 2 Peraturan Menteri dalam Negeri Republik Indonesia Nomor 113 Tahun 2014 Tentang Pengelolaan Keuangan Desa menyebutkan bahwa: 1). Keuangan desa dikelola berdasarkan asas-asas transparan, akuntabel, partisipatif serta dilakukan dengan tertib dan disiplin anggaran; 2). Pengelolaan keuangan desa sebagaimana dimaksud pada ayat (1), dikelola dalam masa 1 (satu) tahun anggaran yakni mulai tanggal 1 Januari sampai dengan tanggal 31 Desember.

Pelaksanaan pengelolaan keuangan desa di dalam lingkungan pemerintahan, ada beberapa asas yang harus di perhatikan, antara lain adalah sebagai berikut:

Asas transparan, artinya memberikan informasi keuangan yang terbuka dan jujur kepada masyarakat berdasarkan perimbangan bahwa masyarakat memiliki hak untuk mengetahui secara terbuka dan menyeluruh atas pertanggung jawaban pemerintah dalam pengelolaan sumber daya yang dipercaya kepadanya dan ketaatannya pada peraturan perundang-undangan. Transparan adalah prinsip yang menjamin akses atau kebebasan bagi setiap orang untuk memperoleh informasi tentang penyelenggaraan pemerintahan, yakni informasi tentang kebijakan, proses pembentukan dan pelaksanaan, serta hasil-hasil yang dicapai.

Akuntabel, artinya tata kelola pemerintahan yang baik merupakan salah satu tuntutan masyarakat yang harus dipenuhi. Salah satu pilar tata kelola tersebut adalah akuntabilitas." Akuntabilitas 


\section{Jurnal Cakrawala Hukum I Volume 9 No. 1 Juni 2018}

ISSN PRINT 2356-4962 ISSN ONINE 2598-6538

atau pertanggungjawaban (accounttability) merupakan suatu bentuk keharusan seseorang (pimpinan/pejabat/ pelaksanaa) untuk menjamin bahwa tugas dan kewajiban yang diembannya sudah dilaksanakan sesuai ketentuan yang berlaku. Akuntabilitas dapat dilihat melalui laporan tertulis yang informatif dan transparan".

Partisipasi, artinya prinsip dimana bahwa setiap warga desa pada desa yang bersangkutan mempunyai hak untuk terlibat dalam setiap pengambilan keputusan pada setiap kegiatan yang diselenggarakan oleh pemeritahan desa dimana mereka tinggal. Keterlibatan masyarakat dalam rangka pengambilan keputusan tersebut dapat secara langsung dan tidak langsung, serta dilakukan dengan tertib dan disiplin anggaran.

Amat penting untuk diperhatikan bahwa dalam pengelolaan keuangan desa haruslah berpedoman pada perinsip-prinsip akuntabilitas hal ini dapat dicapai dengan cara sebagai berikut: 1 . Harus ada komitmen dari pimpinan dan seluruh staf instansi untuk melakukan pengelolaan pelaksanaan misi agar akuntabel; 2. Harus merupakan suatu sistem yang dapat menjamin penggunaan sumber daya secara konsisten dengan peraturan perundang-undangan yng berlaku; 3. Harus dapat menunjukan tingkat pencapaian tujuan dan sasaran yang telah ditetapkan; 4. Harus berorientasi pada pencapaian visi dan misi serta hasil dan manfaat yang diperoleh; 5. Harus jujur, obyektif, transparan dan inovatif sebagai katalisator perubahan management instansi pemerintah dalam bentuk pemutakhiran metode dan teknik pengukuran kinerja dan penyusunan laporan akuntanbilitas (Definisipengertian.com, 2015).

Sumber pendapatan desa yang berasal selain dari APBN/APBD adalah sebagai berikut; a.) Pendapatan Asli Desa antara lain hasil usaha, hasil aset, swadaya dan partisipasi, gotong royong, dan lain-lain pendapatan asli Desa. Menurut penjelasan Pasal 72 ayat (1) Undang-Undang Nomor 6 Tahun 2014 Tentang Desa dinyatakan "Pendapatan Asli Desa” adalah pendapatan yang berasal dari kewe- nangan Desa berdasarkan hak asal usul dan kewenangan skala lokal Desa, yang dimaksud dengan "hasil usaha" termasuk juga hasil BUM Desa dan tanah bengkok; b.) Hibah pihak ketiga yang tidak mengikat; c.) Lain-lain Pendapatan Desa yang Sah;, penjelasan Pasal 72 ayat (1) Undang-Undang Nomor 6 Tahun 2014 Tentang Desa yang dimaksud dengan "lain-lain pendapatan Desa yang sah" adalah antara lain pendapatan sebagai hasil kerja sama dengan pihak ketiga dan bantuan perusahaan yang berlokasi di Desa.

Pertama, Penerapan asas bruto dalam pengelolaan sumber pendapatan desa sebagaimana dimaksud Pasal 91 PP Desa memiliki konsekuensi semua penerimaan desa termasuk yang bersumber dari pengelolaan hasil usaha termasuk tanah bengkok harus melalui kas desa. Kedua, Belanja Desa Dalam Pasal 74 Undang-Undang Nomor 6 Tahun 2014 Tentang Desa, penggunaan dan pemanfaatan Belanja Desa diprioritaskan untuk memenuhi kebutuhan pembangunan yang disepakati dalam Musyawarah Desa dan sesuai dengan prioritas Pemerintah Daerah Kabupaten/Kota, Pemerintah Daerah Provinsi, dan Pemerintah.

Kebutuhan pembangunan sebagaimana dimaksud tidak terbatas pada kebutuhan primer, pelayanan dasar, lingkungan, dan kegiatan pemberdayaan masyarakat Desa. Penjelasan Pasal 74 Undang-Undang Nomor 6 Tahun 2014 Tentang Desa menyatakan dalam penetapan belanja Desa dapat dialokasikan insentif kepada rukun tetangga (RT) dan rukun warga (RW) dengan pertimbangan bahwa RT dan RW walaupun sebagai lembaga kemasyarakatan, RT dan RW membantu pelaksanaan tugas pelayanan pemerintahan, perencanaan pembangunan, ketertiban, dan pemberdayaan masyarakat Desa. yang dimaksud dengan "tidak terbatas" adalah kebutuhan pembangunan di luar pelayanan dasar yang dibutuhkan masyarakat Desa. yang dimaksud dengan "kebutuhan primer" adalah kebutuhan sandang, pangan dan papan. yang dimaksud dengan "pelayanan dasar" adalah 


\section{Akuntabilitas Keuangan Desa dan Kesejahteraan Aparatur Desa dalam Pengelolaan Keuangan Desa}

Yusuf Eko Nahuddin

antara lain pendidikan, kesehatan, dan infrastruktur dasar.

Pelaporan dan pertanggungjawaban APB Desa dilakukan oleh Kepala Desa kepada Bupati/ Walikota. Laporan Kepala Desa kepada Bupati/ Walikota diklasifikasikan dalam 3 bentuk yakni laporan realisasi semesteran, laporan pertanggungjawaban pelaksanaan APB Desa dan laporan penyelenggaraan pemerintahan desa sebagaimana dimaksud Pasal 103 dan 104 PP Desa.

\section{Kesejahteraan Aparatur Desa}

Asumsi umum, kesejahteraan memiliki korelasi dengan perilaku koruptif. Menurut Erna Witoelar dalam hasil survey nasional mengenai korupsi di Indonesia yang dilakukan Kemitraan bagi Pembaruan Tata Pemerintahan Indonesia dinyatakan rendahnya penghasilan sebagai penyebab utama dikuti kurangnya pengawasan dan akuntabilitas para aparatur. Namun demikian penelitian secara empiris sebab-sebab korupsi dinyatakan bahwa sifat- sifat organisatoris dari lembagalah yang menjadi penyebab utama dibandingkan dengan aspek-aspek lain seperti penghasilan (Kemitraan.or.id, 2002). Hasil penelitian dimaksud menegaskan bahwa perilaku koruptif salah satu penyebabnya adalah rendahnya penghasilan para aparatur.

Penghasilan Kepala Desa dan Perangkat Desa (selanjutnya disebut aparatur desa) dalam peraturan perundang-undangan yang baru dapat kita lihat dalam Pasal 66 Undang-Undang Nomor 6 Tahun 2014 Tentang Desa dan Pasal 81 PP Desa bersumber dari ADD. Lebih lanjut pengalokasian penghasilan tetap aparatur desa secara rinci diatur dalam Pasal 81 ayat (1) Penghasilan tetap kepala Desa dan perangkat Desa dianggarkan di dalam PP Desa sebagai berikut: ayat (2) Pengalokasian Pengalokasian ADD untuk penghasilan tetap kepala desa.

Penghasilan tetap aparatur desa berdasarkan Peraturan Pemerintah Nomor 72 Tahun 2005 tentang Desa bersumber dari ADD, namun demikian perhitungan ADD yang yang dibagikan kepada desa dan peruntukan untuk belanja penghasilan tetap aparatur desa diatur dalam Penjelasan Pasal 68 ayat (1) huruf c sebagai berikut; yang dimaksud dengan "bagian dari dana perimbangan keuangan pusat dan daerah" adalah terdiri dari dana bagi hasil pajak dan sumberdaya alam ditambah dana alokasi umum setelah dikurang belanja pegawai. Dana dari Kabupaten/Kota diberikan langsung kepada Desa untuk dikelola oleh Pemerintah Desa, dengan ketentuan 30\% (tigapuluh per seratus) digunakan untuk biaya operasional pemerintah desa dan BPD dan 70\% (tujuh puluh per seratus) digunakan untuk kegiatan pemberdayaan masyarakat.

Peningkatan penghasilan aparatur desa saat ini merupakan konsekuensi dari bertambahnya sumber pendapatan desa yakni pendapatan dari APBN (Dana Desa). Tuntutan pengelolaan keuangan desa yang akuntabel menjadi sebuah keniscayaan untuk tercapainya pemerataan kesejahteraan sebagaimana yang menjadi cita-cita kemerdekaan bangsa ini. Namun demikian agar pengelolaan keuangan desa menjadi lebih akurat, akuntabel pemerintah perlu sesegera mungkin menerbitkan aturan pelaksana teknis terkait pengelolaan keuangan desa.

\section{Simpulan}

Berlakunya Undang-Undang Nomor 6 Tahun 2014 Tentang Desa dan PP Desa merupakan langkah perbaikan dari pemerintah terhadap kesejahteraan desa dan aparaturnya. Peningkatan kesejahteraan aparatur desa merupakan tuntutan atas bertambahnya sumber- sumber pendapatan desa. Perbaikan kesejahteraan dimaksud diharapkan merupakan langkah pencegahan dan upaya meminimalisir kasus-kasus penyalahgunaan keuangan desa.

Namun demikian agar pengelolaan keuangan desa menjadi lebih akurat, akuntabel, Pemerintah perlu segera menerbitkan aturan teknis pelaksanaan pengelolaan keuangan desa yang baru dan diharapkan menjadi pedoman bagi perencanaan, 


\section{Jurnal Cakrawala Hukum I Volume 9 No. 1 Juni 2018}

ISSN PRINT 2356-4962 ISSN ONINE 2598-6538

penggunaan, penatausahaan dan pertanggungjawaban keuangan desa sehingga lebih akuntabel.

\section{Daftar Pustaka}

Definisi-pengertian.com, Prinsip-Prinsip Akuntabilitas Di Indonesia, (online), 4 Oktober 2015.

Hukumonline.com, KPK Siap Antisipasi Potensi Korupsi Dana Bantuan Desa, (online), 11 Desember 2014.

Kansil. 1984. Desa Kita Dalam Peraturan Tata Pemerintahan Desa, Cetakan Pertama, Penerbit Ghalia Indonesia.

Kemitraan.or.id, Survey Nasional Mengenai Korupsi di Indonesia, (online), Februari 2002.
Kompas.com, Alokasi Dana Desa di RAPBN 2015 Belum Sesuai Amanat UU, (online), 16 Agustus 2014.

Solekhan, Moch. 2012. Penyelenggara Pemerintah Desa, Penerbit Setara Press.

Peraturan Pemerintah Nomor 43 Tahun 2014 Tentang Peraturan Pelaksanaan Undang-Undang Nomor 6 Tahun 2014 Tentang Desa.

Sukasmanto, Potensi Penyalahounaan Dana Desa dan Rekomendasi, 4 thIndonesia Anti-Corruption Forum 10-12 Juni 2014

Undang-Undang No. 6 Tahun 2014 Tentang Desa

Vivanews.co.id, Kepala Desa Demo Tuntut Pengesahan RUU Desa, (online) 4 Oktober 2010.

Sujarweni, Wiratna. 2015. Akuntansi Desa, Cetakan Pertama, Penerbit Pustaka Baru Press. 